\title{
Characterization and optimization of production process of alcoholic fermentation of pineapple
}

\section{Caracterização e otimização do processo de produção do fermentado alcoolico de abacaxi}

\author{
Andryelle Geovana Santos Rabelo', Suseanne Kedma de Melo Santos", \\ Germana Arruda de Queiroz"II
}

\section{Abstract}

Fruits are natural sources of vitamins, minerals, carbohydrates and other nutrients. Tropical fruits are consumed and appreciated all over the world due to the taste and flavour. This work aims to evaluate the physicochemical composition of fermented pineapple beverages, study associated fermentation kinetics and optimize fermentation conditions through the use of multiple linear regression and surface response analysis. Pineapple juice was characterized physiochemically using measures of soluble solids (brix), acidity, density and pH. It was determined that a fermentation temperature of $25^{\circ} \mathrm{C}$, pH between 3.0 and 4.0, and inoculum quantity of $4-5 \mathrm{~g} \cdot \mathrm{L}-1 \mathrm{resulted}$ in a high-quality fermented beverage with $8.1 \%(\mathrm{v} / \mathrm{v})$ ethanol content. A kinetic study was performed on the alcoholic fermentation process, monitoring the following variables: Brix, acidity, density, and alcohol content. The results showed that higher concentrations of yeast results in higher productivity and was possible to optimize the processes to maximize the results. This process is technically viable and can yield a value-added product that can generate revenue as well as other significant economic benefits for the beverage market.

Keywords: Fermentation; Optimization; Kinetics; Pineapple; Physicochemical; Beverages

\section{Resumo}

Frutas são fontes naturais de vitaminas, minerais, carboidratos e outros nutrientes. Frutas tropicais são consumidas e apreciadas em todo o mundo devido ao gosto e sabor. Este trabalho tem como objetivo avaliar a composição físicoquímica de bebidas fermentadas de abacaxi, estudar a cinética de fermentação e otimizar as condições de fermentação através do uso de regressão linear múltipla e análise de resposta superficial. O suco de abacaxi foi caracterizado fisico-quimicamente utilizando medidas de sólidos solúveis ( ${ }^{\circ}$ brix), acidez, densidade e pH. Foi determinado que uma temperatura de fermentação de $25^{\circ} \mathrm{C}$, pH entre 3,0 e 4,0 e quantidade de inóculo de $4-5 \mathrm{~g} \cdot \mathrm{L}-1 \mathrm{resultou}$ em uma bebida fermentada de alta qualidade com $8,1 \%(\mathrm{v} / \mathrm{v})$ de etanol. Um estudo cinético foi realizado no processo de fermentação alcoólica, monitorando as seguintes variáveis: ${ }^{\circ}$ Brix, acidez, densidade e teor alcoólico. Os resultados mostraram que concentrações mais altas de levedura resultam em maior produtividade e foi possível otimizar os processos para maximizar os resultados. Este processo é tecnicamente viável e pode gerar um produto de valor agregado que pode gerar receita, além de outros benefícios econômicos significativos para o mercado de bebidas.

Palavras-chave: Fermentação; Otimização; Cinética; Físico-química; Bebidas fermentadas 


\section{Introduction}

Brazil is one of the largest fruit producers in the world, an achievement that has garnered many economic benefits including increased employment and development in several cities. Unfortunately, there are also many problems related to waste. Raw materials easily degrade, and in the commercialization process, all fruits must have quality for the internal and external markets, consistent with a standard profile, without defects including shells, sizes, colouring, consistency, among other factors (TESSARO et al., 2010). This post-harvest waste is a serious problem and generates many losses (GOMES, 2007). An alternative for minimizing these problems is the investment in biotechnological processes and the agroindustry in order to transform waste from this raw material into a viable product. This solution would enable a reduction in postharvest losses and further develop rural areas (DIAS, SCHAWN and LIMA, 2003; GOMES, 2007; FONTAN, 2011). Utilization of fruit juice not only reduces waste, but also creates additional value. As an example, there are some fruits such as apple, peach and pineapple.

Pineapple (Ananas comosus) is a monocotyledonous plant of the bromeliaceous family in the subfamily Bromelioideae. The pineapple is among the most well-known tropical fruits in the whole world, not only due to its flavour and aroma characteristics, but also because of its nutritional composition such as water, mineral salts, carbohydrates, proteins, organic acids, pigments, and vitamins. The quantity of sugar in tropical fruits is a favourable characteristic for application in biotechnological processes, such as, alcoholic fermentation. Fermentation is a natural process for obtaining energy, which is still performed by microorganisms like fungi and bacteria, and widely accepted today as a technique for developing new products (MUNDARAGI; THANGADURAI, 2017). Alcoholic fermentation is widely used for the production of alcoholic beverages. The chemical equation of alcoholic fermentation is as follows (1):

$$
\mathrm{C}_{6} \mathrm{H}_{12} \mathrm{O}_{6} \longrightarrow 2 \mathrm{CH}_{3} \mathrm{CH}_{2} \mathrm{OH}+2 \mathrm{CO}_{2}+\text { Energy }
$$

Wine is considered to be one of the oldest alcoholic fermented beverages, which is generally obtained by maturing natural fruit juice, mainly that of grape (Vitis vinifera). The other fruits used for beverage fermentation are referred to by the name of the fruit, as in this work on alcoholic fermented pineapple (CORAZZA; RODRIGUES, 2001).

Saccharomyces cerevisiae is the main yeast used for fermentation. Yeast consumes the sugar in the fruit, specifically sucrose, glucose, and fructose, effectively turning them into alcohol. Temperature control is an important consideration during alcoholic fermentation that can, in this case, facilitate the growth of microorganisms (ARROYO-LÓPEZ et al., 2009; MUNDARAGI; THANGADURAI, 2017).

The speed of the reaction can be analyzed through a kinetic study. It is important to understand the transformation of the substrate into the product, and measure the velocities of cell growth, substrate consumption, and product formation (MELO, 2011; BORZANI, 2001). There are many works on fermentation kinetics surrounding the behaviour of the grape, but similar work is less common for other fruits. An investigation into the production, yield, and efficiency are essential components in the overall analysis of the process (PAVLAK et al., 2011).

The optimization of the process, used to maximize the yield of the product, can be calculated through several statistical approaches (Matlab, Origin e Excel). These statistical tools are used and applied in bioprocess technology to analyse the influence of soluble solids and yeast concentration in the alcoholic fermentation process (percent conversion and productivity). The most important consideration is that the tool provides accurate results and have good efficacy.

Thus, the main aim of this study is to investigate alcoholic fermented pineapple production through physicochemical characterization, evaluation of alcoholic fermentation kinetics, and linear regression analysis to propose a statistically significant probabilistic model for alcoholic fermentation.

\section{Materials and methods}

\subsection{Materials}

The materials used for the fruit fermentation process were pineapple purchased in supermarket, 4 litres fermenter without temperature control, crystal Sugar (sucrose) purchased in supermarket, distilled water, commercial instant dry yeast (Dr. Oetker brand), ${ }^{\circ} \mathrm{Brix}, \mathrm{pH}$, acidity, density, and alcohol content using a DMA $4500 \mathrm{M}$ digital densimeter manufactured by Anton Paar, $\mathrm{pH}$ papers, an industrial blender in stainless steel blender to beat the pineapple, a filter paper and Gelatine (Royal brand) to clarify the fermented.

\subsection{Manufacture of fermented beverages}

An industrial blender was used to prepare and homogenize the fruit juice, comprising a total volume of 1.0 L. The juice was kept at rest for $1 \mathrm{~h}$, with a measured $\mathrm{pH}$ of 3.0. While the juice was resting, a syrup was prepared by dissolving the sugar in hot water and letting the mixture cool. Subsequently, the syrup was put inside of fermenter at room temperature, followed by the yeast (Saccharomyces cerevisiae), and finally the fruit juice. The whole mixture was then homogenized using a glass stick. Before closing the fermenter, the $\mathrm{pH}$ was verified to be between 3.0 and 4.0. A small reactor was placed next to the larger fermenter in order to, with the aid of a hose, collect the carbon dioxide produced during fermentation. This design effectively prevented external air contamination and facilitated observation of the fermentation process from beginning to end, specifically the intensity of bubble release in the attached tube. The reactors were maintained at room temperature for 15 days. The product was clarified using colourless gelatine at a concentration 
of $1 \mathrm{~g} \cdot \mathrm{L}^{-1}$ (TORRES NETO et al., 2006). At the end of the fermentation process the fermented beverage was removed from the fermenter and was heated to $65^{\circ} \mathrm{C}$ for $20 \mathrm{~min}$ to thereby be conserved into a bottle for longer at room temperature.

\subsection{Kinetic, product formation and substrate consumption}

Kinetic studies were conducted on the fermented beverage using must aliquots obtained periodically throughout the fermentation. The fermenter was opened for a few minutes and the aliquots were measured with the apparatus. Measurements were taken at $1 \mathrm{~h}$ intervals for the first $24 \mathrm{~h}$ of the process, and at increasingly longer intervals until the end of fermentation. For each of the must aliquots, four experimental measurements were taken: Brix, density, alcohol, and acidity.

\subsection{Yield, Productivity and Kinetic parameters of alcoholic fermentation}

The yield $(\mathrm{R})$ of the alcoholic fermentation, expressed as a percentage, quantitatively evaluates the efficacy of the yeast in converting sucrose into ethanol. The yield, $\mathrm{R}(\%)$, and the productivity, $\operatorname{Pr}\left(\mathrm{g} \cdot \mathrm{L}^{-1} \cdot \mathrm{h}^{-1}\right)$, of the production process were calculated using Equations 2 and 3 (LOPES and SILVA, 2006):

$$
\begin{aligned}
& R=\frac{P_{\text {exp }}}{P_{\text {teo }}} \times 100 \\
& \mathrm{P}=\frac{P_{\text {exp }}}{t}
\end{aligned}
$$

$P_{\text {exp }}=$ concentration $(\mathrm{mol} / \mathrm{L})$ of experimental ethanol,

$P_{\text {teo }}=$ concentration $(\mathrm{mol} / \mathrm{L})$ of theoretical maximum ethanol (stoichiometric), and

$t=$ fermentation time $(h)$.

The product yield $\left(\mathrm{Y}_{\mathrm{p} / \mathrm{s}}\right)$ was calculated using Equation 4 (ALMEIDA et al., 2006);

$$
Y_{p / s}=\frac{P_{f}-P_{0}}{S_{0}-S_{f}}
$$

$\mathrm{P}_{0}$ and $\mathrm{P}_{\mathrm{f}}=$ initial and final ethanol (mol. $\left.\mathrm{L}^{-1}\right)$ concentrations;

$\mathrm{S}_{0}, \mathrm{~S}_{\mathrm{f}}=$ the initial and final sucrose concentrations $\left(\mathrm{mol} \cdot \mathrm{L}^{-1}\right)$, respectively.

\subsection{Statistic analysis}

To statistically analyse the influence of the input variable (concentration of soluble solids) on the response variables (percent conversion and productivity). The excel program was used to apply linear regression and variance analysis and the Origin program was used to plot graphics.

\section{Results and discussion}

\subsection{Process for obtaining the fermented fruit}

The three stages of the fermentation process are outlined in Tables 1 and 2. Table 1 provides values for the fermentation process parameters used to produce the fermented beverage, and Table 2 provides values of soluble solid content in ${ }^{\circ}$ Brix, acidity $\left(\mathrm{g} \cdot \mathrm{L}^{-1}\right)$, density $\left(\mathrm{kg} \cdot \mathrm{m}^{-3}\right)$, and $\mathrm{pH}$ before fermentation process.

Table 1- values of process of fermentation

\begin{tabular}{cccc}
\hline $\begin{array}{c}\text { Formulation } \\
\text { of must }\end{array}$ & added sugar (g) & $\begin{array}{c}\text { water } \\
\text { added } \\
(\mathrm{mL})\end{array}$ & $\begin{array}{c}\text { juice vol- } \\
\text { ume (L) }\end{array}$ \\
\hline & 300 & 150 & 0.9 \\
\hline $\begin{array}{c}\text { Formulation } \\
\text { of inoculum }\end{array}$ & $\begin{array}{c}\text { amount of yeast } \\
\left(\mathrm{g} . \mathrm{L}^{-1}\right)\end{array}$ & ${ }^{\circ} \mathrm{Brix}$ & $\mathrm{pH}$ \\
\hline & 6 & 27.6 & 3.0 \\
\hline
\end{tabular}

Table 2 - Pineapple juice before fermentation process

\begin{tabular}{cc}
\hline & Pineapple \\
\hline Brix & 5.0 \\
\hline Density $\left(\mathrm{kg} / \mathrm{m}^{3}\right)$ & 1.017 \\
\hline Acidity $\left(\mathrm{g} . \mathrm{L}^{-1}\right)$ & 1.018 \\
\hline $\mathrm{pH}$ & 3.5 \\
\hline
\end{tabular}

\subsection{Physical and chemical characterization}

Table 3 provides the values and characteristics of fermented beverages in the final 7 days of fermentation. The main parameters analyzed were soluble solid content in ${ }^{\circ}$ Brix, acidity $\left(\mathrm{g} \cdot \mathrm{L}^{-1}\right)$, density $\left(\mathrm{kg} \cdot \mathrm{m}^{-3}\right)$, alcohol, turbidity, and $\mathrm{pH}$.

Table 3 - Physical and chemical parameters

\begin{tabular}{ccccccc}
\hline & ${ }^{\circ}$ Brix & $\begin{array}{c}\text { Acidity } \\
\left(\mathrm{g} / \mathrm{cm}^{3}\right)\end{array}$ & $\begin{array}{c}\text { Density } \\
\left(\mathrm{kg} / \mathrm{m}^{3}\right)\end{array}$ & $\begin{array}{l}\text { Alcohol } \\
(\% \mathrm{v} / \mathrm{v})\end{array}$ & $\begin{array}{l}\text { Turbidity } \\
(\mathrm{NTU})\end{array}$ & $\mathrm{pH}$ \\
\hline Pineapple & 6 & 0.9982 & 987.3 & 8.1 & 1461 & 3.7 \\
\hline
\end{tabular}

The physicochemical analysis of the pineapple fermentation was compared with works in the literature. As shown in Table 4, the $\mathrm{pH}$ of pineapple falls within the optimum $\mathrm{pH}$ range (3.5 to 4.5 ) for fermentation conduction (LOPES and SILVA, 2006). Table 4 lists the values for $\mathrm{pH}$, ${ }^{\circ}$ Brix, and alcohol content measurements for pineapple and others tropical fruits to verify if there are also many differences in relation to the fermentation process. The comparison verifies that the parameters evaluated for the fermented pineapple do not differ considerably from 
those of the other fermented fruits. The $\mathrm{pH}$ measurement is prevalent in industrial alcoholic fermentations because of its importance in bacterial contamination control, fermentation rates, by-product formation, and yeast growth (JONES et al., 1981).

According to Aquarone et al. (1983), the pH range between 3.8 and 4.0 allows for rapid alcoholic fermentation in addition to the inhibition of undesirable bacteria. Based on this information, the pineapple juice used in this study falls within the appropriate $\mathrm{pH}$ range to perform a successful fermentation. Our product yielded an ethanol content of $8.1 \% \mathrm{v} / \mathrm{v}$ at $20^{\circ} \mathrm{C}$ and presented characteristics similar to those fermented in accordance with current legal standards. However, in order to verify the beverage's acceptance in the market, more studies are needed to determine its sensory and conservation characteristics, among others.

The quantity of sugar stabilized as a consequence of the non-fermentable compounds present in the medium (AQUARONE et al., 2001). The use of yeast (Saccharomyces cerevisiae) was adequate to obtain an alcoholic content within the standards required for alcoholic fermentation. Silva (2008) found that ideal yeast concentrations for ethanol production is approximately $20 \mathrm{~g} \cdot \mathrm{L}^{-1}$. Table 4 - Comparison of the composition of the
fermentation of pineapple

\begin{tabular}{|c|c|c|c|c|}
\hline Fruits & $\mathrm{pH}$ & ${ }^{\circ}$ Brix & $\begin{array}{l}\text { Alcohol } \\
\% v / v\end{array}$ & References \\
\hline Pineapple & 3.7 & 6.0 & 8.1 & This work \\
\hline Pineapple & 3.8 & 7.0 & - & $\begin{array}{c}\text { Belchior et al., } \\
2013\end{array}$ \\
\hline Pineapple & 3.1 & 14 & 12.3 & $\begin{array}{c}\text { Oliveira et al., } \\
2012\end{array}$ \\
\hline Watermelon & 4.1 & 6.0 & 10.0 & Fontan et al., 2011 \\
\hline Orange & 3.3 & 8.0 & 10.6 & $\begin{array}{c}\text { Corazza, } \\
\text { Rodrigues e } \\
\text { Nozaki, } 2001\end{array}$ \\
\hline Caja & 2.6 & 0.0 & 12.0 & $\begin{array}{l}\text { Dias, Schawn e } \\
\text { Lima, } 2003\end{array}$ \\
\hline
\end{tabular}

\subsection{Kinetics of alcoholic fermentation}

Figure 1 illustrates the fermentative kinetics of the fermented pineapple beverage. This graphic shows the substrate consumption $(\mathrm{S})$ and ethanol production $(\mathrm{P})$ profiles, each expressed as $\mathrm{g} \cdot \mathrm{L}^{-1}$, as a function of the fermentation time. In the first $24 \mathrm{~h}$, sucrose decreased, and ethanol production increased dramatically. According to Silva (2009), the control variables in the fermentation process are very important for a production that is high in quality and safe for consumption. Substrate and product concentrations stabilized around $45 \mathrm{~h}$ of fermentation, with values of 60 $\mathrm{g} \cdot \mathrm{L}^{-1}$ and $65 \mathrm{~g} \cdot \mathrm{L}^{-1}$ respectively. According to Aquarone et al. (2001), the stabilization of the sugar content is explained by the presence of fermentation inhibitory compounds, like the alcohol in the medium.
Figure 1 - Sugar consumption and ethanol production as a function of time of cultivation of Saccharomyces cerevisiae

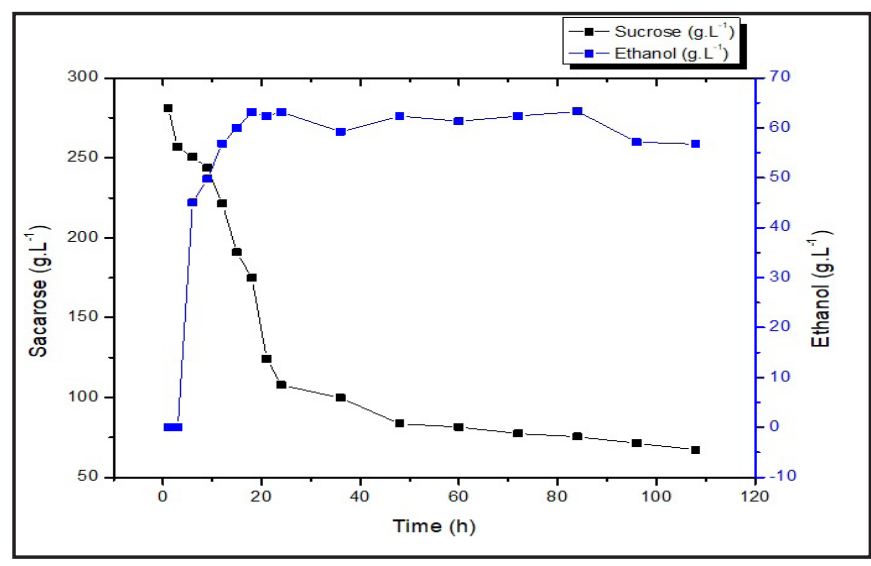

The conversion of the substrate into ethanol began to occur $15 \mathrm{~h}$ after fermentation process was initiated. While studying the preparation of fermented cashews, Torres Neto et al. (2006) observed that at around $10 \mathrm{~h}$ of fermentation, the microorganism reaches the middle of the adaptation phase.

Table 5 shows the kinetic profiles of the must throughout fermentation. The physicochemical parameters analyzed during the first 5 days of the fermentation process were ${ }^{\circ}$ Brix, acidity, density, and alcohol. The results verify the continuous decay of sugar content in the pineapple throughout fermentation. The acidity parameter experienced little variation throughout the process. Similarly, there was also little variation in the density of the fermented pineapple, falling almost always within the range of $0.900-0.999 \mathrm{~g} \cdot \mathrm{cm}^{-3}$. Finally, alcohol production became evident after $6 \mathrm{~h}$ of fermentation.

Table 5 - Fermentative kinetics

\begin{tabular}{|c|c|c|c|c|}
\hline Time (h) & Brix $^{\circ}$ & Acidity & Density & Alcohol (\%v\v) \\
\hline 1 & 27,6 & 1,116 & 1,114 & 0 \\
\hline 3 & 25,2 & 1,004 & 0,999 & 0 \\
\hline 6 & 24,6 & 0,973 & 0,951 & 5,7 \\
\hline 9 & 23,9 & 0,917 & 0,940 & 6,3 \\
\hline 12 & 21,7 & 0,871 & 0,909 & 7,2 \\
\hline 15 & 18,7 & 0,811 & 0,934 & 7,6 \\
\hline 18 & 17,1 & 1,073 & 0,974 & 8 \\
\hline 21 & 12,1 & 1,045 & 0,970 & 7,9 \\
\hline 24 & 10,5 & 1,041 & 0,974 & 8 \\
\hline 36 & 9,7 & 0,948 & 0,917 & 7,5 \\
\hline 48 & 8,1 & 1,024 & 0,900 & 7,9 \\
\hline 60 & 7,9 & 1,025 & 0,907 & 6,5 \\
\hline 72 & 7,5 & 1,013 & 0,930 & 7,8 \\
\hline 84 & 7,3 & 1,006 & 0,907 & 8,0 \\
\hline 96 & 6,9 & 1,005 & 0,949 & 7,9 \\
\hline 108 & 6,5 & 1,006 & 0,955 & 8,02 \\
\hline
\end{tabular}


Table 6 presents the results of yield ethanol, productivity, yield (Yp/s) of pineapple fermented.

Table 6 - Fermentation parameters at the end of the process

\begin{tabular}{cccc}
\hline Fruits & Yield (\%) & $\begin{array}{c}\text { Productivity } \\
\text { (g/L·h) }\end{array}$ & YP/S \\
\hline Pineapple & 45 & 1,30 & 0,44 \\
\hline
\end{tabular}

The results in Table 6 were compared to those reported in the literature of other fermented fruit studies. Some parameters for pineapple juice indicated a low efficacy comparatively, such as the conversion percentage contrasted with the mandacaru fruit (91.82\%) (ALMEIDA et al., 2007). Fontan et al. (2011) similarly achieved a high conversion percentage $(94.0 \%)$ in the production of fermented watermelon, in addition to a productivity of $1.65 \mathrm{~g} \cdot \mathrm{L}^{-1} \cdot \mathrm{h}^{-1}$. In this study, the product yield obtained in relation to the substrate $\left({ }^{\circ} \mathrm{Brix}\right)$ was 6.5 . On the other hand, lower values were obtained for the conversion percentage (55.166) and the product yield substrate (0.282). Through such comparisons, it is possible to affirm that the parameters determined in this research, namely conversion percentage, productivity, and product yield in relation to the substrate, are reasonably within the ranges of the related literature. Therefore, the production of fermented pineapple on a commercial scale is viable, provided that modifications are made to some experiments and technical feasibility is achieved.

\subsection{Statistic analyse}

In order to examine the influence of input variables, including soluble solid and yeast concentrations, on the response variables, such as conversion and productivity, experimental data was submitted to a multiple linear regression analysis using the Excel program. This step was performed in an effort to optimize the processes and define the optimal ranges of process operations to maximize the results.

Equations 5 and 6 show the empirical regression models of the experimental data, adjusted for the conversion $(\%)$ and productivity $\left(\mathrm{g} \cdot \mathrm{L}^{-1} \cdot \mathrm{h}^{-1}\right)$ of the fermented pineapple, respectively.

Conversion $(\%)=218-60.8 \mathrm{Y}+0.306 \mathrm{~B}$

$\operatorname{Productivity}\left(\mathrm{g} \cdot \mathrm{L}^{-1} \cdot \mathrm{h}^{-1}\right)=-287.8+104.28 \mathrm{Y}-0.57 \mathrm{~B}$

Where $\mathrm{Y}$ and $\mathrm{B}$ represent yeast concentration $\left(\mathrm{g} \cdot \mathrm{L}^{-1}\right)$ and ${ }^{\circ}$ Brix, respectively. Table 7 shows the results that were obtained throughout the process using the equation 3 and 4.

The coefficients are statistically significant at the $95 \%$ confidence interval for the pineapple fermentation. Tables 8 presents the parameters of the variance analysis (coefficient of determination $\mathrm{R}^{2}$ and test $\mathrm{F}$ ) for model adjustment.
Table 7 - Conversion and productivity of the fermented pineapple

\begin{tabular}{cccc}
\hline Yeast (g.L ${ }^{-1}$ ) & Brix (g.L - $\left.^{-1}\right)$ & Productivity & $\begin{array}{c}\text { Conversion } \\
(\%)\end{array}$ \\
\hline 5 & 281,03 & 112,25 & 0,00 \\
\hline 4,8 & 256,72 & 33,04 & 0,00 \\
\hline 4,5 & 250,64 & 15,97 & 31,91 \\
\hline 4,2 & 243,55 & 10,22 & 35,27 \\
\hline 4 & 221,27 & 6,66 & 40,30 \\
\hline 3,9 & 190,88 & 4,23 & 42,54 \\
\hline 3,7 & 174,67 & 3,04 & 44,78 \\
\hline 3,5 & 124,02 & 2,30 & 44,22 \\
\hline 3,3 & 107,81 & 2,04 & 44,78 \\
\hline
\end{tabular}

Table 8 - Parameters of the variance analysis for the percent conversion and productivity of the fermented pineapple

\begin{tabular}{ccc}
\hline Parameters & \% Conversion & Productivity $\left(\mathrm{g} \mathrm{L}^{-1} \mathrm{~h}^{-1}\right)$ \\
\hline $\mathrm{R}^{2}$ & $\sim 0,80$ & 0,75 \\
\hline test $F$ & 36,9 & 6,34 \\
\hline $\mathrm{F}_{\text {calculated }} / \mathrm{F}_{\text {tabulated }}$ & 6,38 & 1,23 \\
\hline
\end{tabular}

The conversion and productivity models presented in Equations 5 and 6 are proven statistically significant by satisfactory coefficients of determination $\left(\mathrm{R}^{2}\right)$ and $\mathrm{F}_{\text {calculated }} / \mathrm{F}_{\text {tabulated }}$ ratios above 1 at the $95 \%$ confidence interval (BARROS NETO et al., 1995). Thus, the operating ranges of the input variables can be maximized through the analysis of a response surface graph. Figures 2 and 3 show the coefficient determination graphs.

Figures 4 and 5 show the effects of the input variables, ${ }^{\circ}$ Brix and yeast concentration, on the response variables, conversion and productivity. Figure 4 illustrates the conversion (\%) increase and indicates that the influence of Brix is greater than the initial concentration of yeast on the conversion (\%) response. The highest conversions were obtained when the amount of yeast was lower.

As illustrated in Figure 5, the two input variables (Brix and yeast concentration) influence the response (productivity). Evidently, with the increase of yeast concentrations, the productivity of the process increases. Large amounts of brix and small amounts of yeast decrease the productivity parameter. According to Parente (2014) the increase in yeast concentration provides a higher productivity increase than the increase in soluble solids concentration, showing that the yeast concentration exerts a greater influence on the productivity than the soluble solids concentration. The fermentation process demonstrated that higher concentrations of yeast result in higher productivity; however, the conversion is independent of yeast. Alternatively, based on the analysis of the Brix parameters, higher concentrations of Brix correlated with high conversion percentage results. 
Figure 2 - Graphs coefficients of determination (R2) of productivity in relation to ${ }^{\circ}$ Brix

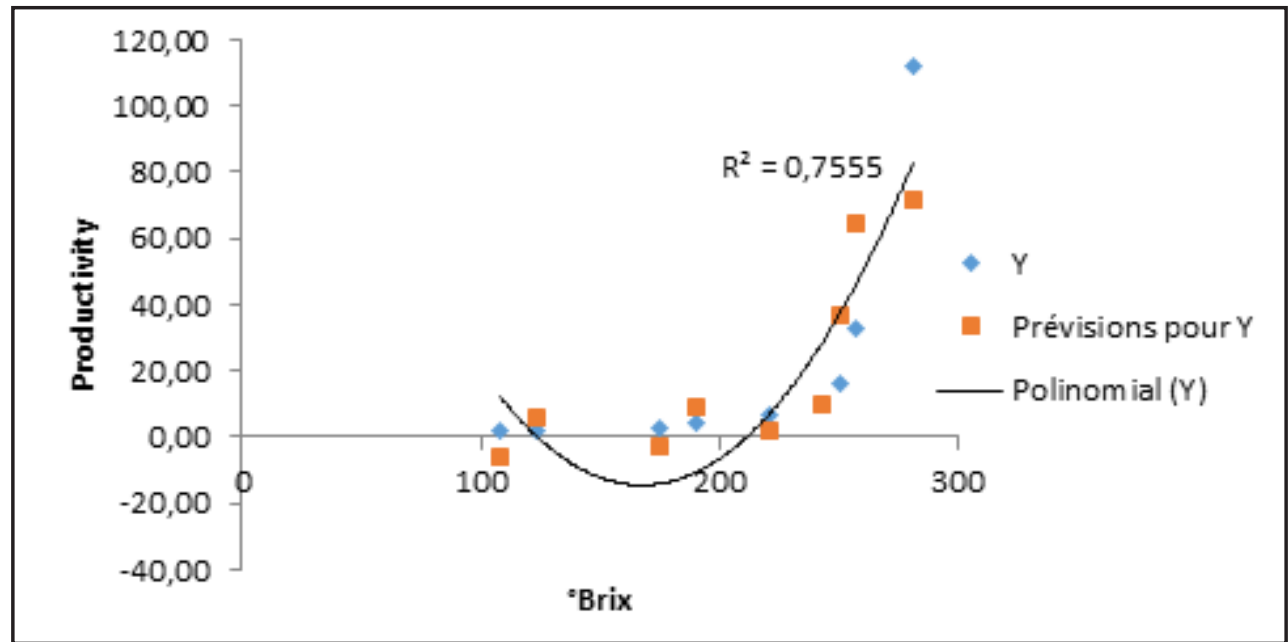

Figure 3 - Graphs coefficients of determination (R2) of percent conversion as a function of ${ }^{\circ}$ Brix

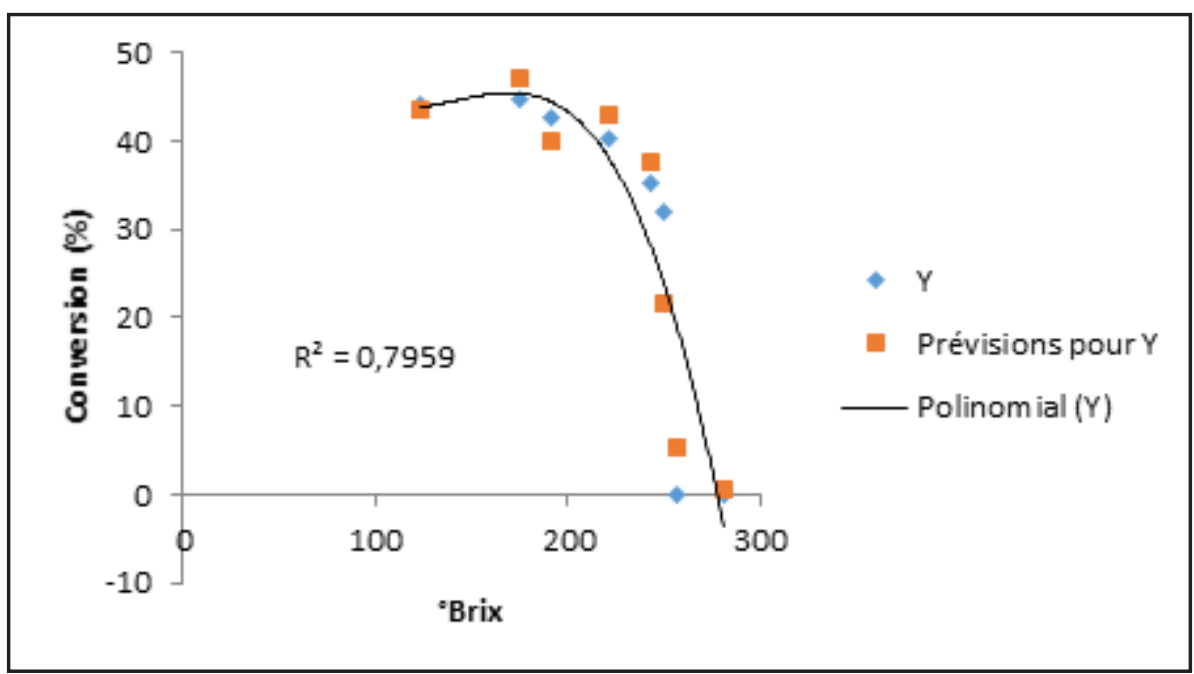

Figure 4 - Response surface of the percent conversion as a function of Brix and yeast concentrations

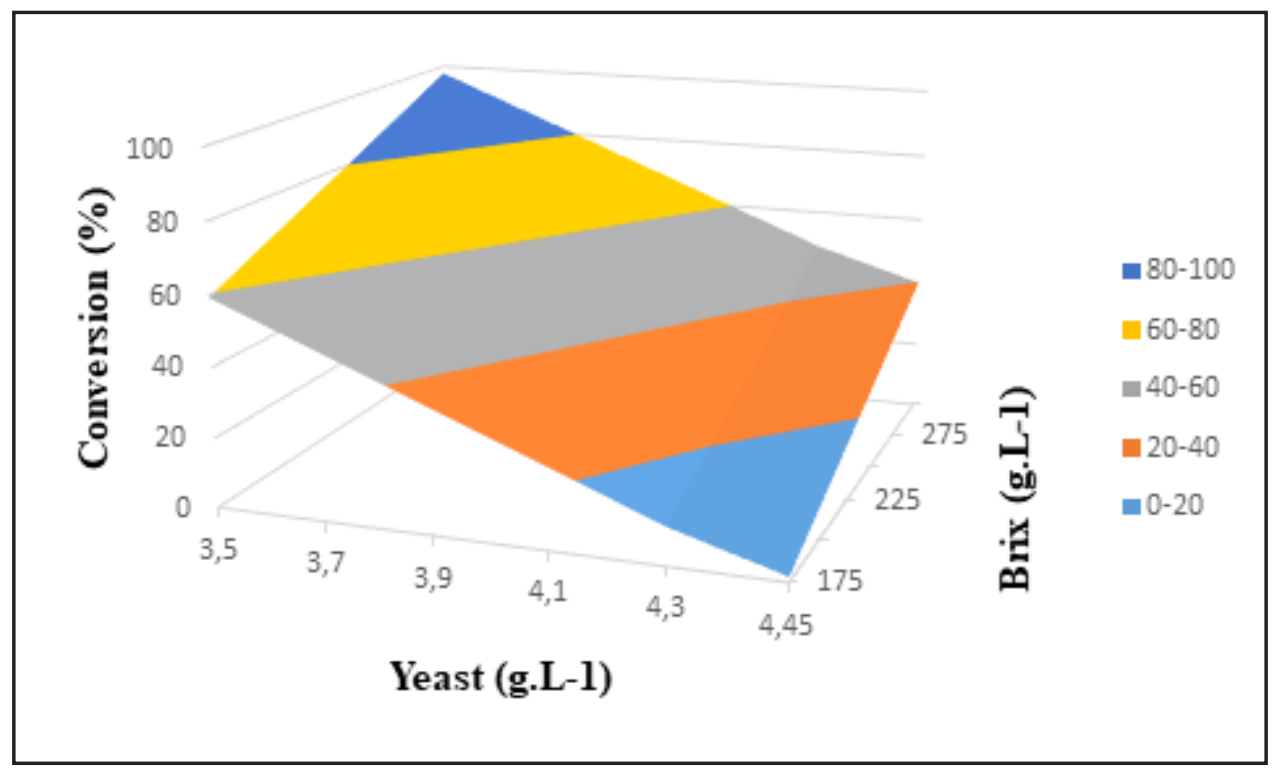


Figure 5 - Response surface of the productivity as a function of ${ }^{\circ}$ Brix and yeast concentrations

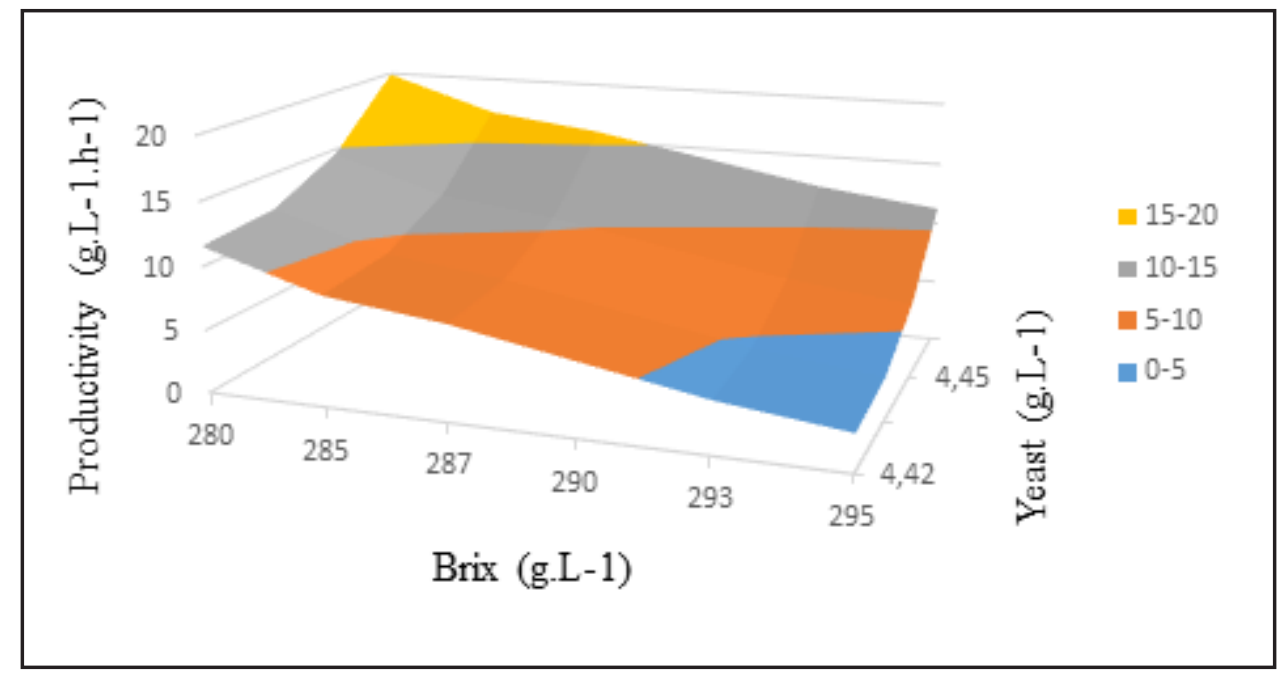

\section{Conclusions}

We developed a process for alcoholic pineapple fermentation that is technically feasible. The results of the fermentation indicate that higher concentrations of yeast results in higher productivity; however, the conversion percentage is independent of the yeast concentration. The resulting product had characteristics similar to those of other fruit ferments reported in the literature. The must remained in fermentation for 20 days; however, $48 \mathrm{~h}$ into the process, no further change was observed in either the substrate or product concentrations. The fermentation parameters obtained demonstrate that the commercial yeast Saccharomyces cerevisiae performed satisfactorily in the alcoholic fermentation process of pineapple juice. For large-scale production, final adjustments to the production process are necessary.

\section{Acknowledgments}

Thanks to the UniFBV Wyden institution for the support for the development of this work.

\section{References}

ALMEIDA, M. M. Estudo da bioconversão do mandacaru (Cereus jamacaru P. DC.) para produção de bioprodutos. Campina Grande: UFCG/CCT, 2007. 145p. (Tese de Doutorado).

AQUARONE. E.; BORZANI. W.; SCHIMIDELL. W.; LIMA. U.A. Biotecnologia Industrial: biotecnologia na produção de alimentos. São Paulo: Edgard Blücher Ltda, 2001.

AQUARONE. E.; LIMA. U. A.; BORZANI. W. Alimentos e bebidas produzidos por fermentação: biotecnologia. São Paulo: Edgard Blücher, 1983. v. 5, 43 p.
ARROYO-LÓPEZ. F. N.; ORLIĆ. S.; QUEROL. A.; BARRIO. E. Effects of temperature, $\mathrm{pH}$ and sugar concentration on the growth parameters of Saccharomyces cerevisiae, S. kudriavzevii and their interspecific hybrid. International Journal of Food Microbiology, 131(2-3), 120-127, 2009. PMid:19246112. Available at: <http://dx.doi. org/10.1016/j.ijfoodmicro.2009.01.035>

BARROS NETO. B.; SCARMINIO. J. S.; BRUNS. R. E. Planejamento e Otimização de Experimentos. 1a edição. São Paulo: Editora Unicamp, 1995. 401p.

BELCHIOR, Diana Cléssia Vieira; TEIXEIRA, Wéllida Patrícia Aviz; MONTEIRO, Wancicléia de Jesus; SARAIVA, Althiéris de Souza; SANTOS, Claudia Cristina Auler do Amaral. PRODUÇÃO DE FERMENTADO ALCOÓLICO A PARTIR DE ABACAXI (Ananas Comosus L.). $9^{\circ}$ Seminario de Iniciação cientifica, Campus Palma, ano 2013, 29 nov. 2013.

BORZANI, W. Processo biotecnológico industrial genérico. In: BORZANI, W; SCHMIDELL, W; LIMA, U. A; AQUARONE, E. Fundamentos. São Paulo: Edgard Blücher, 2001. cap. 9, p. 249-252, vol. 1

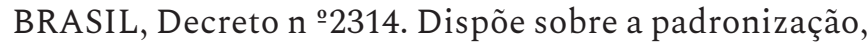
a classificação, o registro, a inspeção, a produção e a fiscalização de bebidas. Diário Oficial da República Federativa do Brasil, 1997.

CARVALHO, R. A.; OLIVEIRA, E. F.; LACERDA, J. T.; NETO, M. B.; ARAUJO, J. X. Controle alternativo da fusariose do abacaxi. In: SIMPOSIO INTERNACIONAL DO ABACAXI, 6., 2007, João Pessoa, Anais... João Pessoa, PB, 2007. p. 96.

CORAZZA, M. L.; RODRIGUES, D. G. Preparação e caracterização do vinho de laranja. Quimica Nova, v. 24, n. 4, p. 449-452, 2001. 
DIAS, D. R.; SCHAWN, R. F.; LIMA, L. C. O. Metodologia para elaboração de fermentado de cajá (Spondias mombin L.). Ciência e Tecnologia de Alimentos, Campinas, v. 23 n. 3, p. 342, set./dez. 2003

FONTAN, R. C. I.; VERÍSSIMO, L. A. A.; W. S.; BONOMO, R. C. F.; VELOSO, C. M. Cinética da fermentação alcoólica na elaboração de vinho de melancia. Bol. Cent. de Pesq. de Proces. de Alim., Curitiba, v. 29, n. 2, p. 203-210, jul./ dez. 2011

GOMES, P. Fruticultura brasileira. 13 ed. São Paulo: Nobel, 2007. 446 p.

JONES. R. P.; PAMMENT. N.; GREENFIELD. P. F. 1981. Alcohol fermentation by yeasts-the effects of environmental and other variables. Process Biochem., April/May, 42-49.

LOPES, R. V. V.; SILVA, F. L. H. Elaboração de fermentados a partir do figo-da-india. Revista de Biologia e Ciências da Terra, v. 6, n. 2, p. 305-315, 2006

MUNDARAGI, Abhishek, \& THANGADURAI, Devarajan. Process optimization, physicochemical characterization and antioxidant potential of novel wine from an underutilized fruit Carissa spinarum L. (Apocynaceae). Food Science and Technology, 38(3), 428-433, 2018.

OLIVEIRA, L. A.; LORDELO, F. dos S.; TAVARES, J. T. de Q.; CAZETTA, M. L. Elaboração de bebida fermentada utilizando calda residual da desidratação osmótica de abacaxi (Ananas comosus L.). Revista Brasileira de Tecnologia Agroindustrial, Paraná, ano 2012, v. 06, n. 06, p.702-712, ed. 01, 2012.

PARENTE, G. D. L. Cinética da fermentação e da destilação na produção de aguardente de abacaxi. 2014. 75 f. Dissertação (Mestrado em Sistemas Agroindustriais) - Universidade Federal de Campina Grande, Centro de Ciências e Tecnologia Agroalimentar, Campina Grande, 2014.

PAVLAK, M. C. M.; ABREU-LIMA, T. L.; CARREIRO, S. C.; PAULILLO, S. C. L. Estudo da fermentação do hidrolisado de batata-doce utilizando diferentes linhagens de Saccharomyces cerevisiae. Química Nova, São Paulo, 2011, vol.34, n.1, pp. 82-86.ISSN 0100- 4042. Available at: <http://www.scielo.br/pdf/qn/v34n1/v34n1a16.pdf>. Accessed on 11 de março de 2013.

SILVA, J. A.; DAMASCENO, B. P. G. de L., SILVA, F. L. H. da, MADRUGA, M. S., \& SANTANA, D. P. de. Aplicação da metodologia de planejamento fatorial e análise de superfícies de resposta para otimização da fermentação alcoólica. Química Nova, 31(5), 1073-1077, 2008.
SILVA, D.F.P. da; SIQUEIRA, D. L. de; PEREIRA, C. S; SALOMÃO, L.C.C; STRUIVING, T.B. Caracterização de frutos de 15 cultivares de mangueira na Zona da Mata mineira. Revista Ceres, Viçosa, v. 56, n.6, p. 783-789, nov/dez, 2009.

TESSARO, D.; LARSEN, A. C.; DALlAGO, R. C.; DAMASCENO, S. G.; SENE, L.; COELHO, S. R. M. Avaliação das fermentações alcoólica e acética para produção de vinagre a partir de suco de laranja. Acta Scientiarum. Technology, Maringá, v. 32, n. 2 p. 201205, 2010. 